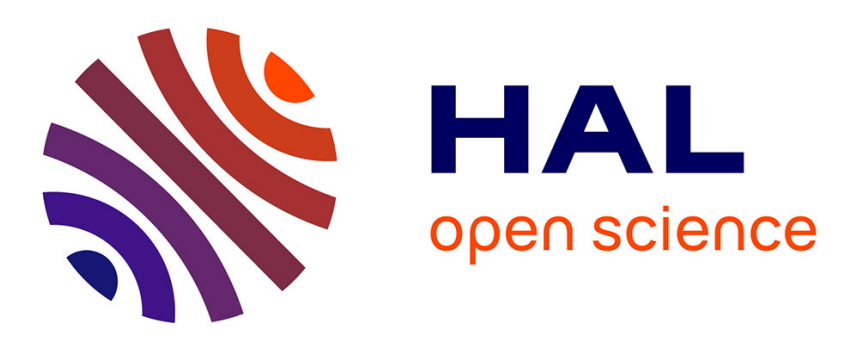

\title{
Total catalytic oxidation of a side-product for an autothermal restoring hydrogen process
}

\author{
P. Kerleau, Y. Swesi, V. Meille, I. Pitault, F. Heurtaux
}

\section{To cite this version:}

P. Kerleau, Y. Swesi, V. Meille, I. Pitault, F. Heurtaux. Total catalytic oxidation of a sideproduct for an autothermal restoring hydrogen process. Catalysis Today, 2010, 157 (1-4), pp.321-326. 10.1016/j.cattod.2010.02.011 . hal-00527720

\section{HAL Id: hal-00527720 \\ https://hal.science/hal-00527720}

Submitted on 16 Oct 2019

HAL is a multi-disciplinary open access archive for the deposit and dissemination of scientific research documents, whether they are published or not. The documents may come from teaching and research institutions in France or abroad, or from public or private research centers.
L'archive ouverte pluridisciplinaire HAL, est destinée au dépôt et à la diffusion de documents scientifiques de niveau recherche, publiés ou non, émanant des établissements d'enseignement et de recherche français ou étrangers, des laboratoires publics ou privés. 


\section{Total catalytic oxidation of a side-product for an autothermal}

\section{restoring hydrogen process}

P. Kerleau ${ }^{a}$, Y. Swesi ${ }^{a}$, V. Meille ${ }^{a}$, I. Pitault*a ${ }^{* a}$ F. Heurtaux ${ }^{b}$

a: Université de Lyon, CNRS, Laboratoire de Génie des Procédés Catalytiques, CPE Lyon, 43 bd du 11 novembre 1918, BP 82077, 69616 Villeurbanne Cedex, France

b: Renault, Direction des Technologies Automobile Avancées, 78288 Guyancourt, France

*: corresponding author: Dr Isabelle Pitault; Université de Lyon, CNRS, Laboratoire de Génie des Procédés Catalytiques, CPE Lyon, 43 bd du 11 novembre 1918, BP 82077, 69616

Villeurbanne Cedex, France; email: isabelle.pitault@1gpc.cpe.fr; Tel: 33472431761; Fax: 33472431673

Keywords: Combustion; Dehydrogenation; Heat exchanger reactor; Coupling; Coated reactor 
Abstract : The catalytic total oxidation of toluene is used to bring the required calories to restore hydrogen from methylcyclohexane. Two coupled reactions, both catalyzed by Pt/alumina, are thus considered in one autothermal heat-exchanger-reactor (HER): endothermic dehydrogenation of methylcyclohexane and catalytic combustion of less than $10 \%$ of produced toluene ( $6 \%$ for the chemical reaction, about $4 \%$ for heat losses). Both reactions are carried out at $350^{\circ} \mathrm{C}$. Methylcyclohexane and toluene light-off curves have been performed in one elementary module. Methylcyclohexane combustion has been eliminated due to its safety drawbacks, although the $\mathrm{MCH}$ combustion provides best stability to autothermal HER. 


\section{Introduction}

To feed an on-board fuel cell, hydrogen can either be produced in situ by a chemical reaction or chemically or physically stored. The here-studied process consists of releasing hydrogen from naphthenic molecules, hydrogen storing compounds [1-3]. The aromatic compounds, the by-products of the dehydrogenation reaction, can be recycled ex-situ in a hydrogenation plant to restore the hydrogen-rich reactants [4]. The molecules are used as hydrogen carriers. In the global processing system, the hydrogen and aromatics mixture is first separated by condensation at room temperature. Aromatics are afterwards stored in a tank and hydrogen (containing 2\%vol. Aromatics for $\mathrm{MCH} /$ Toluene couple) is then purified using adsorption on polymers. After purification, aromatics content in hydrogen being lower than 1ppm, hydrogen can safety feed a FC [5].

The chosen hydrogen-rich reactant is methylcyclohexane $(\mathrm{MCH})$ because of its high hydrogen storage capacity $(6 \mathrm{wt}-\%)$ and the lower toxicity of the produced toluene (TOL) in comparison with benzene. As dehydrogenation of $\mathrm{MCH}$ is highly endothermic and occurs above $300^{\circ} \mathrm{C}$, heat can be provided by burning toluene with both reactions performed in a catalytic heat exchanger.

The heat exchanger reactors (HER) consist of coupling both reactions (endothermic and exothermic) and recovering the heat produced by the exothermic reaction to heat the endothermic reaction. In this study, to reach highest efficiency in the HER, the oxidation reaction has been performed on coated stainless steel plate walls that are in contact with the dehydrogenation reaction. This configuration corresponds to recuperative mode in Kolios's terminology $[6 ; 7]$. The main advantage of using stainless steel plates is the high thermal conductivity, which reduces the thermal gradient within the walls and the required transfer area. Moreover, the use of structured plates increases the turbulence, which also reduces choking compared with the use of tubes. Nevertheless, high thermal conductivity should also 
be a drawback, it increases heat losses and the energy necessary to ignite the combustion. One of the first catalytic HERs with coated walls was described by Hunter and McGuire [8] in a patent. They presented the use of coated catalyst to improve heat transfer and decrease combustible consumption in a domestic boiler. The flame absence inducing a low production of gas pollutants is presented as an advantage. Their main difficulty was the distribution of heat flows.

The goal of this study is to show the feasibility of coupling a fast exothermic reaction such as combustion with a slow endothermic reaction such as dehydrogenation, focusing on combustion reactors. Firstly, the choice of combustible based on light-off curves and the use of structured plate for combustion are discussed. Secondly, the reactions of dehydrogenation and combustion are independently studied to quantify heat losses and give critical estimates of flows and concentrations suitable to be coupled in an HER. Finally, an improvement in the design of the HER is shown.

\section{Experimental}

Toluene (TOL) is used as received from Acros. It is pumped by a HPLC pump (Gilson 305) and vaporized via a T-junction through a capillary tube perpendicular to the air flow. The TOL-air mixture is preheated up to $180^{\circ} \mathrm{C}$ and introduced into the combustion reactor. The range of operating conditions is $1-3$ Nlair. $\mathrm{min}^{-1}, 1-2.2 \% \mathrm{TOL}, 350-450^{\circ} \mathrm{C}$. The combustion effluents are cooled to room temperature and water is condensed in a Peltier condenser (M\&C Cooler ECP 100) before analysis in ABB detectors $\left(\mathrm{O}_{2}\right.$ : ABB Magnos 106 (Magnetomechanical detector; range 0-100 vol\%); $\mathrm{CO}_{2}$ : ABB Uras 14 (IR absorption; range 0-100 vol \%); $\mathrm{CO}$ : two ABB Uras 14 (IR absorption; ranges 0-1000 ppm and 0-100 vol\%). Each detector is equipped with internal calibration allowing a precision greater than $0.5 \%$.

At the inlet of the dehydrogenation reactor, methylcyclohexane ( $>99 \%$, Acros) is pumped by a HPLC ISMATEC pump (Reglo CPF/FMI 005), vaporised and preheated $\left(250^{\circ} \mathrm{C}\right)$. The 
evaporator is close to the reactor inlet to avoid heat loss. $\mathrm{MCH}$ enters the reactor with a small amount of hydrogen to avoid rapid deactivation of the catalyst. For activation and regeneration purposes, air and $\mathrm{N}_{2}$ can also be fed. The range of operating conditions is 2-11 mlMCH.min ${ }^{-1}, 350-400^{\circ} \mathrm{C}, 1.5$ bars. The dehydrogenation products are condensed by two condensers in series. A smaller third condenser is used to sample products before GC analysis. This configuration is used to protect the Hydrogen detector. $\mathrm{MCH}$ conversions are measured using a GC equipped with PONA column.

The same nature of catalyst is used for combustion and dehydrogenation reactions. It was prepared by wet impregnation of gamma-alumina (SASOL, SBa-200) with a toluenic solution of platinum acetylacetonate allowing $\mathrm{Pt} / \mathrm{Al}_{2} \mathrm{O}_{3}$ catalyst to be obtained. The powder obtained is used in the dehydrogenation reactors. Concerning the combustion reactors, the coated walls were obtained by dip-coating in a suspension of the catalyst in diluted nitric acid, followed by drying and calcination steps.

One single combustion reactor (A) and two different heat-exchanger reactors (B and C) (HER) were designed in the lab and tested in the experimental set-up presented in Figure 1. All reactors and modules are made of stainless steel. The reactors can be heated up to $600^{\circ} \mathrm{C}$ by two copper heating plates positioned above and below the stacks.

\section{Single combustion module (A)}

The single combustion module $(5 \mathrm{~cm}$ long $* 5 \mathrm{~cm}$ wide $* 0.5 \mathrm{~cm}$ thick) is coated with $0.12 \mathrm{~g}$ of 2.1wt-\% Pt/alumina (Figure 2). A Ni-Cr foam is used at the gas inlet to increase the pressure drop and evenly distribute the reactants.

\section{First generation heat-exchanger reactor $(B)$}

It consists of a long and thin dehydrogenation reactor $(15 \mathrm{~cm}$ long $* 5 \mathrm{~cm}$ wide $* 0.4 \mathrm{~cm}$ thick) coupled to 6 combustion reactors $(5 \mathrm{~cm}$ long $* 5 \mathrm{~cm}$ wide $* 0.5 \mathrm{~cm}$ thick) (Figure 3$)$. 
The dehydrogenation reactor is filled with $22 \mathrm{~g}$ of $0.88 \mathrm{wt}-\% \mathrm{Pt} /$ alumina, whereas each combustion reactor contains $0.12 \mathrm{~g}$ of $2.1 \mathrm{wt}-\% \mathrm{Pt} /$ alumina, coated on the heat-exchanging walls. The temperatures are measured with thermocouples located in a space between the combustion modules and the dehydrogenation reactor, one of them being inserted in the powder bed as Figure 4.

\section{Second generation heat-exchanger reactor $(C)$}

The second generation is more compact than the first [9]. Its dimensions are $5.4 \mathrm{~cm}$ long, 5.4 $\mathrm{cm}$ wide and $2.5 \mathrm{~cm}$ high. The HER consists of 6 plates, 4 of them are $4.5 \mathrm{~mm}$ thick and 2 of them (at the top and the bottom of HER) are $3 \mathrm{~mm}$ thick (Figure 5). The four central plates in the HER centre each form half the dehydrogenation reactor on one side and half the combustion reactor on the other side. The 2 end plates comprise only the combustion reactor halves. Each dehydrogenation section consists of one channel $45 \mathrm{~cm}$ long (4mm wide, $3 \mathrm{~mm}$ high), containing a mean of $4.6 \mathrm{~g}$ catalyst powder $(200 \mu \mathrm{m}$ diameter particles of $0.5 \mathrm{wt}-$ $\left.\% \mathrm{Pt} / \mathrm{Al}_{2} \mathrm{O}_{3}\right)$ and coiled in a $5.4 \mathrm{~cm} * 5.4 \mathrm{~cm}$ plate. Each combustion section consists of a $5 \mathrm{~cm} * 5 \mathrm{~cm} * 3 \mathrm{~mm}$ chamber $\left(0.7 \mathrm{~g}\right.$ of $\left.2.1 \mathrm{wt}-\% \mathrm{Pt} / \mathrm{Al}_{2} \mathrm{O}_{3}\right)$ containing pillars and wash-coated on its two faces. The HER is equipped with ten thermocouples. Four of them measure inlet and outlet gas temperatures. These temperatures are necessary to calculate the heat balance and loss. The others ( $T_{-} 1$ to $\left.T_{-} 6\right)$ are inserted in the walls between the dehydrogenation and combustion chambers (Figure 6). They give indications of temperature profiles along and across the reactors. The arrows show the flow direction for $\mathrm{MCH}$ in the dehydrogenation reactors. Combustion chambers can be fed in co- or counter-current mode with respect to $\mathrm{MCH}$

For HER B and C, the stacks are first electrically heated up to $360-375^{\circ} \mathrm{C}$, under $\mathrm{N}_{2}$ or air flow through the dehydrogenation and combustion reactors respectively. Then, $\mathrm{MCH}$ is fed to the dehydrogenation reactors. Finally, TOL is injected into the combustion reactors. 


\section{Results}

First generation reactor - 1 single combustion module (configuration A)

In a first part, MCH and TOL combustions were studied in one of the six modules of HER B. The programmed temperature curves (Figure 7) show that the ignition and extinction temperatures of TOL are greater than for $\mathrm{MCH}$. The $\mathrm{MCH}$ extinction curve could not be obtained with the operating conditions in our set-up, heat losses being lower than heat produced by combustion. Although the TOL combustion was unreliable below about $300^{\circ} \mathrm{C}$, toluene was chosen due to the risk of flashback for $\mathrm{MCH}$.

The temperature reached during toluene combustion evidently depends on the air flow rate and the toluene content (Figure 8). Moreover, a temperature gradient between the inlet and the outlet of each combustion module is observed. The localization of the hot spot also varies from the entrance of the module at low toluene fraction to the exit of the module at higher toluene fraction, with a non-linear propagation front, despite the use of the metallic foam as a distributor. Despite the high thermal conductivity of stainless steel and the thickness of the walls, the thermal gradient remains relatively high, about 10 to $15^{\circ} \mathrm{C}$. From these results, the six modules were laid out so as to lightly stagger the 6 hot spots on the both sides of HER B. In this case, the axial thermal flow provided by the modules to the dehydrogenation reactor is more homogeneous.

\section{First generation reactor - 3 top combustion modules (configuration B)}

The global heat-exchanger reactor was validated step by step. Firstly, three combustion modules running together were studied. The temperatures observed at the wall of the different modules are reported for various flow rates and toluene fraction. The difference between the top and the bottom modules is due to the fact that only the top modules are fed with air and toluene. What is more surprising is that the temperature decreases from Ta6 to Ta2, showing 
that the distribution of air and toluene is not the same in each module (Figure 9). To overcome this drawback, the pressure drop in each module was measured and a restriction was added at the entrance to each module to give all modules the same pressure drop. These measures were, however, not sufficient.

\section{First generation reactor - dehydrogenation (configuration B)}

The dehydrogenation reaction was also studied alone. Temperature profiles in the dehydrogenation reactor (central part of the heat-exchanger reactor) (Figure 10) show a large temperature gradient between walls and bed centre. Moreover, the greater the $\mathrm{MCH}$ flow is, the greater the temperature gradient is. This gradient is entirely due to low thermal conductivity of the catalytic bed. On the other hand, the temperature gradients for Ta3 and $\mathrm{Tb} 2$ are quite similar and show the catalytic bed is symmetrical, the thermal flows induced by the dehydrogenation reaction should be equal above and below the dehydrogenation reactor.

\section{First generation reactor - coupling (configuration B)}

Despite the disappointments encountered during the study of each reaction, the coupling of both reactions was attempted (Figure 11). The dehydrogenation is started first, with electrical heating. After 70 minutes, the combustion (in the 6 modules) is started. The temperature rise in the dehydrogenation section is now due only to the calories produced by the combustion modules. The temperature controller reduces the electrical heating to zero. The coupling works, but a very large temperature gradient $\left(50^{\circ} \mathrm{C}\right)$ is observed between the centre of the catalyst bed and the wall at the exit of the reactor. Moreover, the observed temperature gradients in the wall between the reactor entrance and exit using the three modules increase as the dehydrogenation progresses. In this situation, energy produced by combustion at the dehydrogenation reactor entrance provided insufficient heat to the reactor. Whilst, energy produced by combustion at the dehydrogenation reactor exit provided an excess of heat to the 
reactor.

After the all experiments, a single module was disassembled at the end of the combustion experiments. This allowed the observation that the quality of the coating remained good, but some corrosion of the stainless steel (Figure 12) and decomposition of the Ni-Cr foam was also observed. The Ni-Cr was stressed during the temperature change and turned into powder. The presence of black marks suggests homogeneous combustion in the foam.

The second generation reactor was designed with these observations in consideration.

\section{Second generation reactor - coupling (configuration C)}

The internal structures and arrangement of the plates have been designed in order to promote heat transfer between dehydrogenation and combustion catalysts while maintaining ideal plug flow in each reactor. The foam used to homogenize the gas flow was removed and the structures of the combustion plates were designed to break the flow and increase the turbulence. To avoid an axial thermal gradient due to poor gas distribution in the tubes between several modules, a stack of plates was designed with the same entrance box and the same exit box for all combustion plates. The same configuration was chosen for the dehydrogenation chamber entrance and exit.

The main observed behaviours in the HER C (Figure 13) are the following. Temperatures are nearly homogeneous in the HER under electrical heating with no reaction. With electrical heating and $\mathrm{MCH}$ feed, the significant temperature undershoot close to the inlet illustrates the endothermicity of the reaction. The temperature measured at the same distance from the inlet, but at different depths in the stack (T_1\&T_2; $\left.T_{-} 3 \& T_{-} 4\right)$ are close to each other but significantly different. The temperatures measured with the thermocouples furthest from the heating plates are evidently the coldest. $\mathrm{MCH}$ conversions obtained during the periods (2) of Figure 13 are about $85 \%$.

In the second heat-exchanger reactor configuration, the reactors being perfectly symmetrical, 
two different modes of operation were studied: counter-current and co-current. Autothermal conditions are successfully achieved both in co-current and counter-current flow modes. In both cases, the use of central combustion module removes the temperature difference between T_1\&T_2 or T_3\&T_4. Figure 13 clearly shows the advantage of co-current operation. Lower temperature excursions along the reactor and higher $\mathrm{MCH}$ conversions are achieved in cocurrent flow mode than in counter-current flow mode. In co-current flow mode, the coupling occurs at a constant temperature of $330^{\circ} \mathrm{C}$. But, in all cases, $\mathrm{T}_{-} 1$ (resp. T_3) is much closer to T_2 (resp. T_4) because heat supply (combustion) is uniformly spread over the stack depth. The MCH conversions achieved in co-current flow are $78 \%$ against $59 \%$ in counter-current flow. In all cases, TOL combustion is total.

\section{Comparison between HER B and HER C:}

The enthalpies of $\mathrm{MCH}$ dehydrogenation and Toluene combustion being $204 \mathrm{~kJ} / \mathrm{mol}$ and $3771 \mathrm{~kJ} / \mathrm{mol}$ respectively, only $6 \%$ of the produced toluene is necessary to heat the reactor with no heat loss. For HER B and HER C, $10.0 \%$ and $9.7 \%$ of the produced toluene was burned with a $\mathrm{MCH}$ flow of about $3.9 \mathrm{~g} / \mathrm{min}$ and the same hydrogen production. Heat losses are therefore of the same order of magnitude for both laboratory reactors. Moreover, the higher the $\mathrm{MCH}$ flows are, the lower the toluene proportions to compensate for heat loss are (for example, for both the $\mathrm{HER}$, for $5 \mathrm{~g} / \mathrm{min} \mathrm{MCH}$ flow, $7.4 \%$ of the produced toluene is burned and for $2 \mathrm{~g} / \mathrm{min} \mathrm{MCH}$ flow, $13.9 \%$ of the produced toluene is burned). Both reactors have the same efficiency in terms of hydrogen production. However, the HER B is less compact than the HER C. The masses of dehydrogenation catalysts in the reactors are very different: $22 \mathrm{~g}$ of $0.88 \mathrm{wt}-\% \mathrm{Pt}$ (i.e. $193 \mathrm{mg}$ of $\mathrm{Pt}$ ) and $9 \mathrm{~g}$ of $0.5 \mathrm{wt}-\% \mathrm{Pt}$ (i.e. $45 \mathrm{mg}$ of $\mathrm{Pt}$ ) in HER $\mathrm{B}$ and HER $\mathrm{C}$ respectively. The masses of combustion catalysts are $0.7 \mathrm{~g}$ and $2.4 \mathrm{~g}$ of the same 2.1wt-\%Pt in HER B and HER C respectively. In all combustion modules, the reaction is hardly limited by mass and heat transfer, the mass of Pt only affects the reaction rate during 
the ignition step. In conclusion, if the compactness is an effectiveness criterion, the HER $\mathrm{C}$ is better than HER B.

\section{Conclusions - perspectives}

The coupling of one endothermic reaction and one exothermic one in two autothermal heatexchanging reactors was carried out with success.

Present work has concerned the study of different designs of the structured heat-exchanger reactor. It highlighted the problems of corrosion linked to the coating procedure on stainless steel walls. This drawback is what stopped the future process development. Methods to protect walls have to be developed. Nevertheless, both the reactors have dramatically enhanced the efficiency of the dehydrogenation reaction, as the same conversion can not be reached at the same WHSV in classical reactors.

\section{Acknowledgements}

Renault Direction des Technologies Automobile Avancées is warmly acknowledged for the financial support of the present study. 


\section{References}

[1] S. Tschudin, T. Shido, R. Prins \& A. Wokaun, J. Catal. 181 (1999) 113-123.

[2] P. Ferreira-Aparicio, I. Rodriguez-Ramos \& A. Guerrero-Ruiz, Chem. Commun. (2002) 2082-2083.

[3] N. Kariya, A. Fukuoka, T. Utagawa, M. Sakuramoto \& Y. Goto, Appl. Catal. A 247 (2003) 247-259.

[4] Y. Swesi, D. Ronze, I. Pitault, R. Dittmeyer \& F. Heurtaux, Int. J. Hyd. Energy 32 (2007) $5059-5066$.

[5] Y. Swesi, Ph. Kerleau, V. Lamotte, I. Pitault. and D. Ronze, Ind. \& Eng. Chem. Res., 49

(2) (2010), 817-821

[6] G. Kolios, J. Frauhammer \& G. Eigenberger, Chem. Eng. Sci. 55 (2000) 5945-5967.

[7] S. Deshmukh \& D. Vlachos, Chem. Eng. Sci. 60 (2005) 5718-5728.

[8] J. Hunter \& G. McGuire, Patent. Matthey Bishop, inc. (1980) US4214867.

[9] F. Heurtaux, P. Kerleau, I. Pitault \& F. Campoli, Patent. Renault. (2009) FR2927323. 


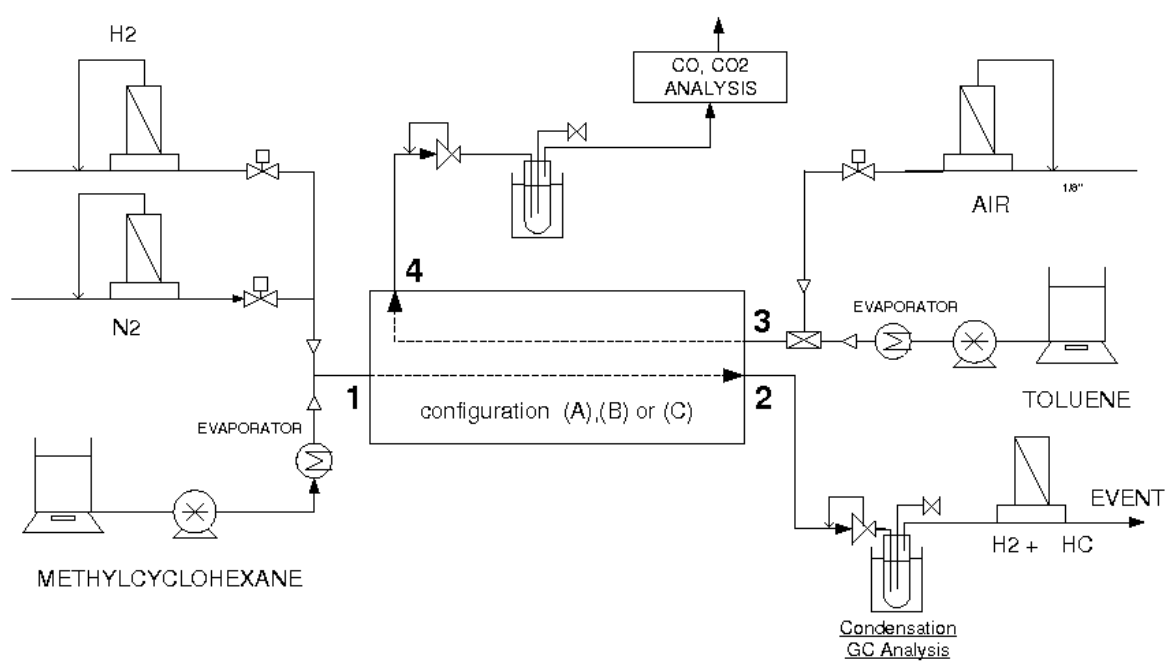

Figure 1. Experimental set-up to carry out the coupling of toluene combustion and methylcyclohexane dehydrogenation.

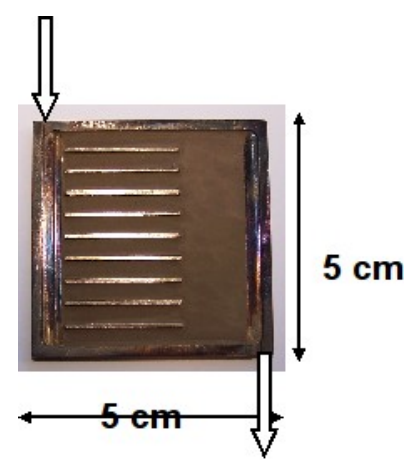

Figure 2. Coated catalyst in the module A structure.

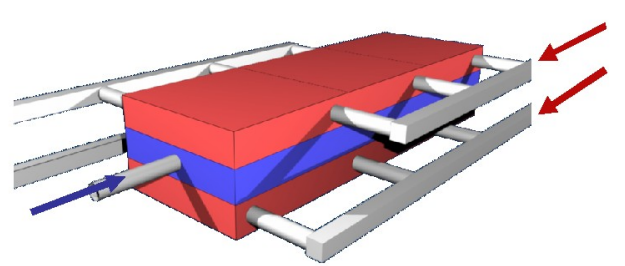

Figure 3. Autothermal reactor (HER B) coupling $\mathrm{MCH}$ dehydrogenation (blue central section) and TOL combustion (red sections). 


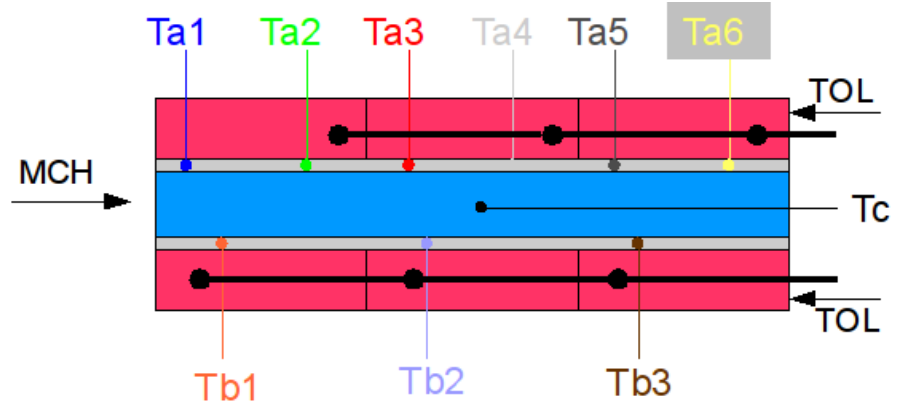

Figure 4. Diagram of thermocouple locations in the autothermal reactor (HER B).
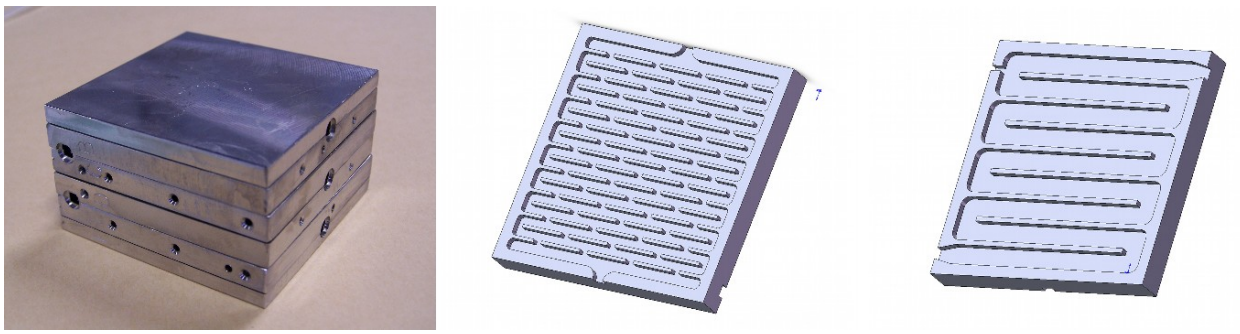

Figure 5. Second generation heat-exchanger reactor (HER C). From left to right: stack of plates, combustion zone, dehydrogenation zone.
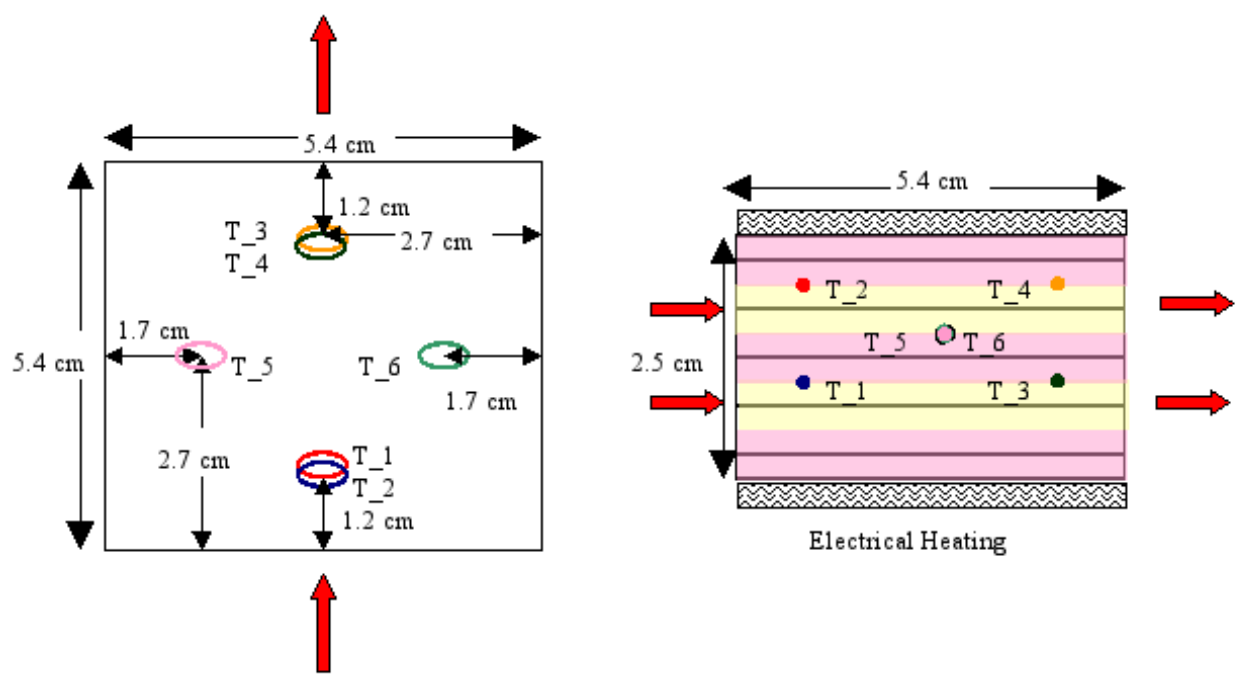

Figure 6. Thermocouple positions in the HER C. Left: top view. Right: side view. Pink rectangles: Combustion chambers. Yellow rectangles: Dehydrogenation Beds. Gray lines: Boundaries of the 6 plates. 


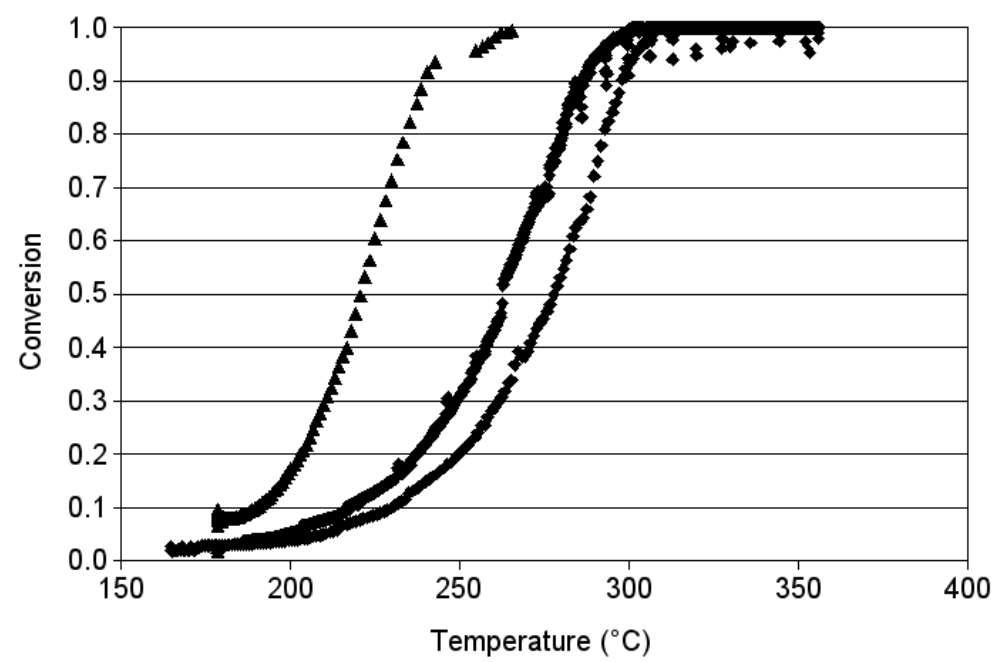

Figure 7. Extinction and ignition curves of combustion of toluene and methylcyclohexane in an elementary box. ( $)$ TOL ignition and extinction $\mathrm{D}_{\mathrm{TOL}}=32 \mu 1 \cdot \mathrm{min}^{-1}, \mathrm{D}_{\mathrm{air}}=0.31_{\mathrm{STP}} \cdot \mathrm{min}^{-1}$. ( $\left.\mathbf{\Delta}\right)$ $\mathrm{MCH}$ ignition $\mathrm{D}_{\mathrm{MCH}}=32 \mu 1 \cdot \mathrm{min}^{-1}, \mathrm{D}_{\text {air }}=0.31_{\mathrm{STP}} \cdot \mathrm{min}^{-1}$.

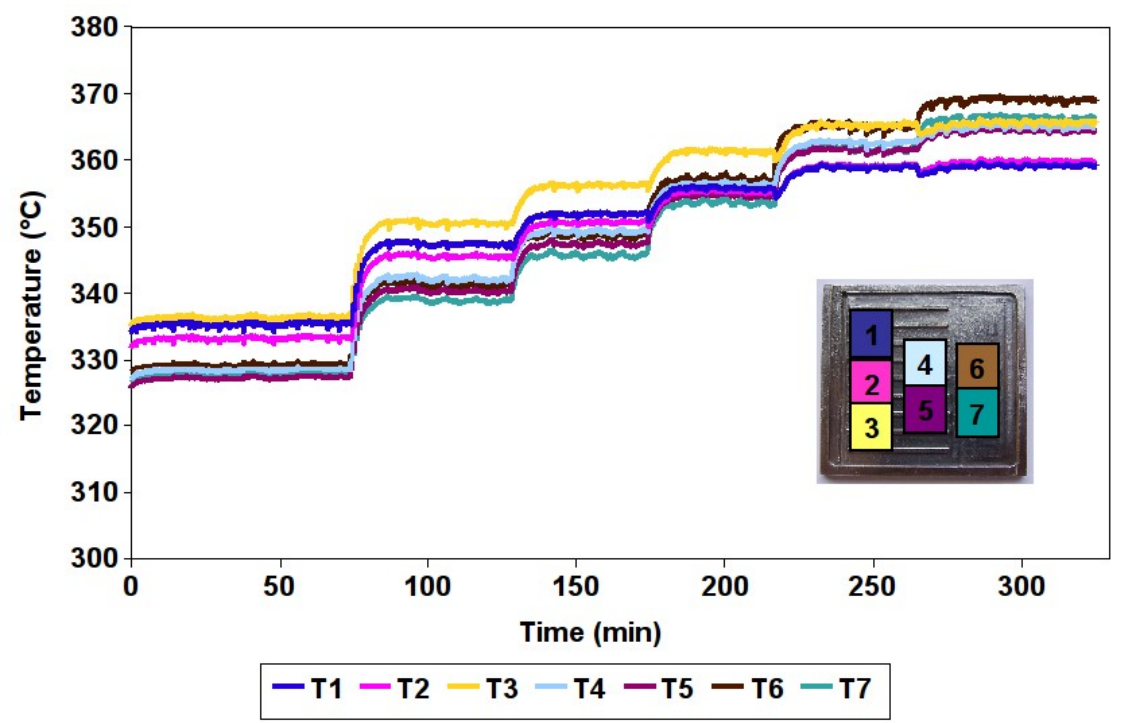

Figure 8. Temperature profiles in one combustion module at different toluene fractions (from left to right: $0.61 \%, 1.21 \%, 1.51 \%, 1.80 \%, 2.09 \%, 2.11 \%) . \quad \mathrm{D}_{\text {air }}=0.31_{\mathrm{STP}} \cdot \mathrm{min}^{-1}$, regulation temperature $=350^{\circ} \mathrm{C}$ 


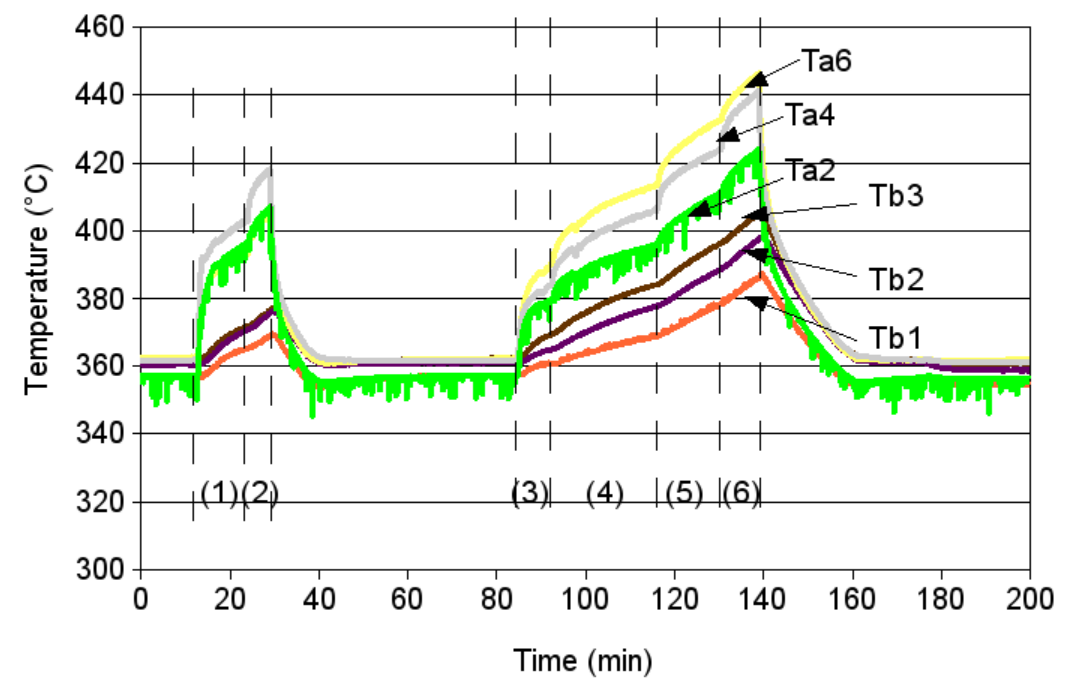

Figure 9. Toluene combustion in the three top modules. The dehydrogenation zone is not active (no reaction) and is fed with nitrogen flow. (1)-(2) $\mathrm{D}_{\text {air }}=2.01_{\mathrm{STP}} \cdot \mathrm{min}^{-1}$; (3)-(6) $\mathrm{D}_{\text {air }}=3.0$ $1_{\mathrm{STP}} \cdot \mathrm{min}^{-1} ;(1) \mathrm{y}_{\mathrm{TOL}}=1.56 \%$; (2) $\mathrm{y}_{\mathrm{TOL}}=2.07 \%$; (3) $\mathrm{y}_{\mathrm{TOL}}=1.05 \%$; (4) $\mathrm{y}_{\mathrm{TOL}}=1.39 \%$; (5) $\mathrm{y}_{\mathrm{TOL}}=1.73 \%$; (6) утоL $_{\text {TOL }} 2.07 \%$.

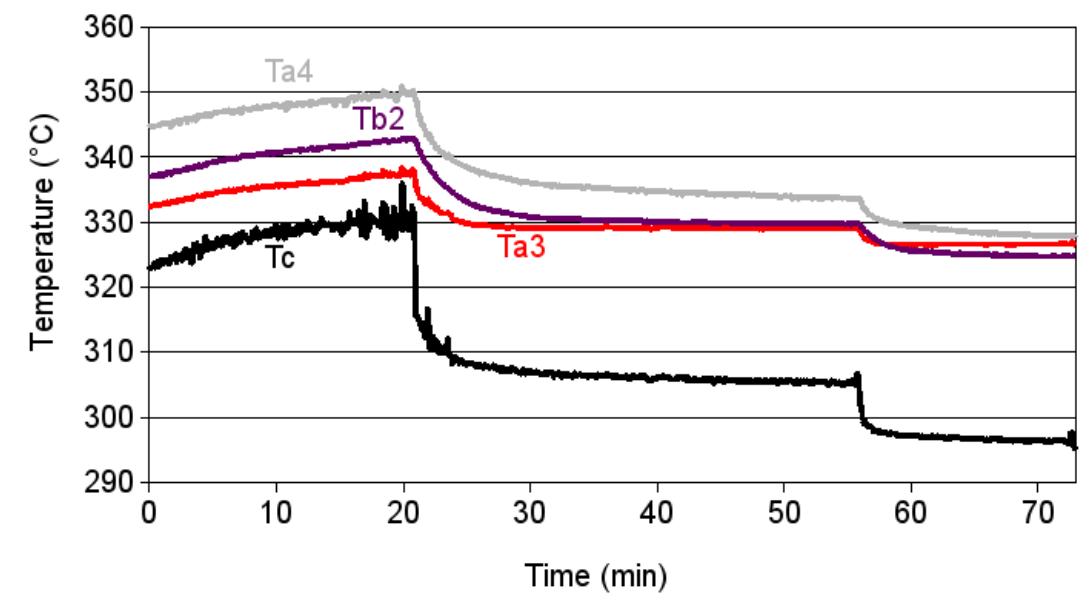

Figure 10. Temperature profiles in the reactor for $\mathrm{MCH}$ dehydrogenation, heat is provided by electric power. Between 0 and $20 \mathrm{~min}, \mathrm{D}_{\mathrm{MCH}}=5 \mathrm{ml} \cdot \mathrm{min}^{-1}$; between 20 and $56 \mathrm{~min}, \mathrm{D}_{\mathrm{MCH}}=7.8$ ml.min ${ }^{-1}$; After 56 min, $\mathrm{D}_{\mathrm{MCH}}=10.4 \mathrm{ml} \cdot \mathrm{min}^{-1}$. 


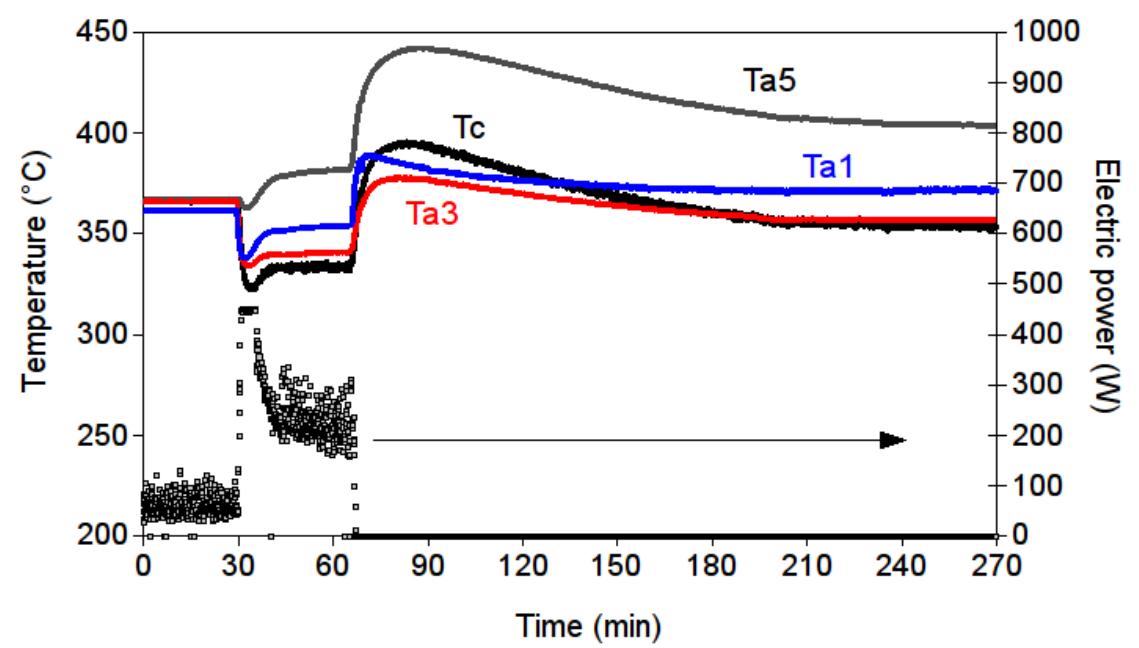

Figure 11. Dehydrogenation and toluene combustion coupling. Preheating with electric power and nitrogen flows. At $30 \mathrm{~min}$, start of $\mathrm{MCH}$ feeding $\left(\mathrm{D}_{\mathrm{MCH}}=3.9 \mathrm{ml} . \mathrm{min}^{-1}\right)$. At $68 \mathrm{~min}$, start of toluene and air feeding $\left(\mathrm{D}_{\mathrm{air}}=2.01_{\mathrm{STP}} \cdot \mathrm{min}^{-1} ; \mathrm{y}_{\text {тоL }}=1.97 \%\right)$.

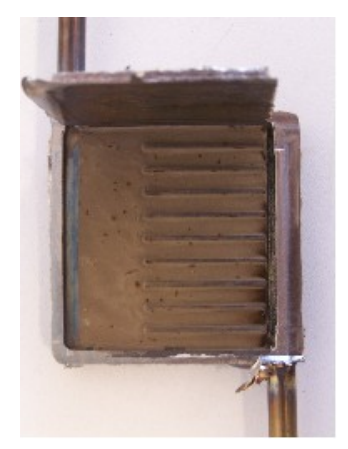

Figure 12. Single combustion module after run. 


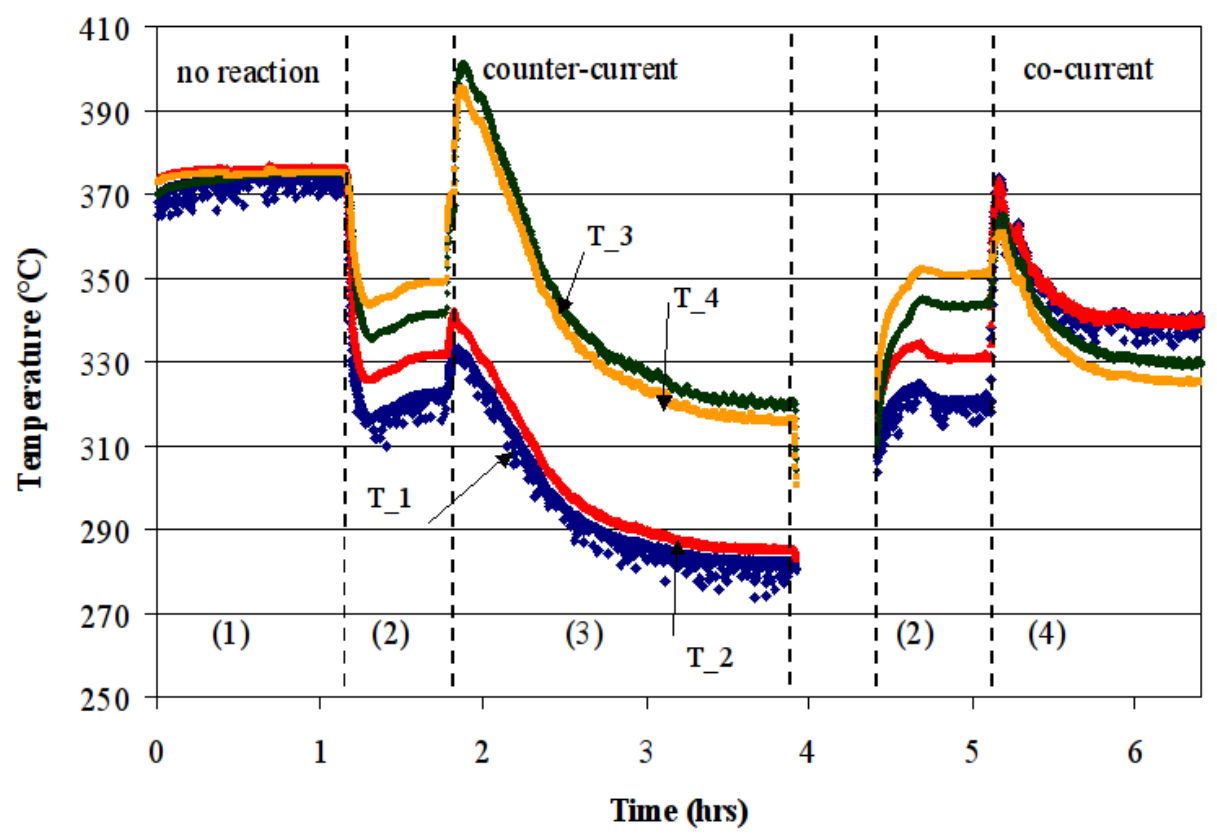

Figure 13. Dehydrogenation and toluene combustion coupling. (1) Preheating with electric power and nitrogen flows at $390^{\circ} \mathrm{C}$. (2) $\mathrm{MCH}$ feeding $\left(\mathrm{D}_{\mathrm{MCH}}=2.3 \mathrm{ml} \cdot \mathrm{min}^{-1}\right)$. (3) Toluene and air feeding $\left(\mathrm{D}_{\text {air }}=31_{\mathrm{STP}} \cdot \mathrm{min}^{-1} ; \mathrm{y}_{\text {TOL }}=0.25 \%\right)$ in counter-current mode. (4) Toluene and air feeding $\left(\mathrm{D}_{\text {air }}=31_{\text {STP }} \cdot \min ^{-1} ;\right.$ УтоL $\left.=0.25 \%\right)$ in co-current mode. 